This is an electronic reprint of the original article. This reprint may differ from the original in pagination and typographic detail.

Author(s): Onkila, Tiina

Title: $\quad$ Pride or Embarrassment? Employees' Emotions and Corporate Social Responsibility

Year: $\quad 2015$

Version:

Please cite the original version:

Onkila, T. (2015). Pride or Embarrassment? Employees' Emotions and Corporate Social Responsibility. Corporate Social Responsibility and Environmental Management, 22(4), 222-236. https://doi.org/10.1002/csr.1340

All material supplied via JYX is protected by copyright and other intellectual property rights, and duplication or sale of all or part of any of the repository collections is not permitted, except that material may be duplicated by you for your research use or educational purposes in electronic or print form. You must obtain permission for any other use. Electronic or print copies may not be offered, whether for sale or otherwise to anyone who is not an authorised user. 


\title{
Pride or Embarrassment? \\ Employees' emotions and corporate social responsibility
}

\begin{abstract}
This study explores how the employees of a financial firm use emotional arguments to construct different views of their employer's corporate social responsibility. It is theoretically based on the recent literature regarding employee perspectives of CSR, and especially on the role of emotions in CSR. Furthermore, the study utilizes rhetorical theory as a framework for data analysis. A qualitative study, based on faceto-face interviews, was conducted among 27 employees in a Finnish financial firm. The study identifies six categories of emotional arguments the employees used to construct views of where their employing organization's CSR is derived from. These categories relate positive emotions to satisfaction with the employing organization's CSR and negative emotions to dissatisfaction. The results show that employees also experience external pressures for CSR, but only implicitly, because they do not wish be embarrassed by their employer.
\end{abstract}

Keywords: Corporate social responsibility, employees, rhetoric, emotions, financing firm

\section{Introduction}

Corporate social responsibility (CSR) is usually conceptualized through different stakeholder groups and their importance to and demands on CSR. The discussion has recently been extended to the importance of employees-not simply as demanders of responsibility in issues such as responsible HRM practices (Celma et al., 2012) but as participating in or initiating, for instance, donations (Haski-Leventhal, 2012). However, the role of employees in how CSR is perceived is under-researched and the literature 
argues for more research on the employees in addressing responsibility in business (Russell and Griffiths, 2008).

Prior research on environmental responsibilities in business has highlighted the importance of emotions to responsibility. Russell and Griffiths (2008, p.85) stated:

While environmental management research does mention emotive components of proenvironmental behavior (Andersson and Bateman, 2000; Bansal and Roth, 2000; Ramus and Steger , 2000), there are very few studies that examine emotion directly.

The importance of emotions was further stressed by Fineman (1996a, p.480):

I wish to argue that pro-environmental organizational changes, like other organizational changes, depend crucially on the emotional meanings that key actors attribute to environmental protection.

However, one finds surprisingly little data on the emotions employees relate to CSR and their consequences for its different meanings. As Russell and Griffiths (2008) point out, while environmental management research has mentioned the emotive components of pro-environmental behavior, there are few studies that examine emotions directly. From an environmental responsibility point of view, these include Fineman's (1996a) and Fineman and Sturdy's (1999) work, whereas solely from a CSR point of view emotions remain unstudied. Still, emotions explicitly brought up by the interviewees were a striking feature in my interviewee material concerning corporate social responsibility and information dissemination in a financial firm.

Prior research on employee roles in CSR has especially maintained employees as a coherent, unified group that demands CSR among other stakeholders (Jamali, 2008; Longo et al., 2005; Royle, 2005; Preuss et al., 2009; McWilliams and Siegel, 2001). In addition, the studies on cultural changes in regards to CSR have aimed at creating such a coherent group by managerial action (Halme, 2002; Siebenhuner and Arnold, 2007; Haugh and Talwar, 2010; Benn and Martin, 2010; Del Brio et al., 2008). Thus the research has focused on asking what the employee demands are on CSR among other stakeholders and how management can motivate employees to participate in CSR. However, a few studies have embraced the different meanings that employees attach to CSR. For instance, Rupp et al. (2006) stressed employees' different judgments of their employing organization's CSR. Still, little is known about the employees' judgments of how their employing organization's CSR is defined and the emotions related to those judgments. 
This encouraged me to conduct a rhetorically oriented study on explicit emotions expressed by employees while talking about their employing organization CSR. The study asks how employees of a Finnish financial firm use explicitly emotional arguments to construct different views of corporate social responsibility. The study shows that employees use emotional arguments to construct distinct views of where their employing organization's CSR is derived from, relating positive emotions to satisfaction with CSR and negative emotions to shortcomings in the employing organization's CSR.

I first review the previous research on CSR, emotions and employees and show its implications for this study. Second, I present the rhetorical approach of the study as well as the research context, material and methods. Finally, I explain the empirical results of the study and discuss the contribution of the study.

\section{Corporate Social Responsibility, Emotions and Employees}

\section{Multiple Meanings of CSR}

The first definitions of corporate social responsibility date back to the 1950s. During this era it held different meanings (Carroll, 1999), from Friedman's (1970) argumentation of profit maximization to more modern definitions encompassing different pillars or dimensions of CSR (Carroll, 1993; Wood, 1991; Elkington, 1997). Although Carroll's work (1993) and Elkington's (1997) triple bottom line are commonly accepted as starting points for a definition of CSR, still many researchers and practitioners contest the term's meaning. For example, Dahlsrud (2008) found 37 definitions for CSR. He concluded that the existing definitions are, to a large degree, congruent and refer to five dimensions: stakeholder, social, economic, voluntariness and environmental. He explains that the confusion is not so much about how CSR is defined, but about how CSR is socially constructed in a specific context. Although there is some agreement on what types of issues can be included in CSR on the macro-level, we still know little of the meanings related to CSR in different microcontexts by different actors. In different contexts CSR can be a contested and disputed 
phenomenon (Dobers, 2009). Contextual factors influence the perceptions and definitions of CSR. This means the current CSR concepts still suffer from a level of abstraction to which Jamali (2008) offers the stakeholder approach as a practical alternative. This approach, too, however, provides few tools for analyzing different meanings of the concept.

\section{Employees' Importance to CSR}

Despite the discussion of the different meanings of CSR, the mainstream literature stresses employees as a unified group and the importance of shared responsibility. A number of streams of research point out that employees, among other stakeholders, demand CSR and note their crucial role in the internal organizational changes for achieving CSR.

First, the stakeholder perspective places employees among key stakeholders concerning CSR (Carroll, 1999; Jamali, 2008; Longo et al., 2005; Royle, 2005; Preuss et al., 2009; McWilliams and Siegel, 2001). Among other stakeholders, they are pushing organizations towards responsible behavior (Aguilera et al., 2007; Williams and Siegel, 2001). Williams and Siegel (2001) identified two major sources of demand for CSR: consumer demand and demand from other stakeholders such as investors, employees and the community. They especially identified the influence of unions, and interest in labor relation policies, safety and financial security. Furthermore, Henriques and Sadorsky (1999) identified four groups that demand firms to protect the natural environment: regulatory stakeholders (government and trade associations), organizational stakeholders (customers, suppliers, employees and shareholders), community stakeholders (community groups and environmental organizations) and the media. Sharma and Henriques (2005) examined how managers' perceptions of different types of stakeholder influences affect the types of sustainability practices that firms adopt. A multiplicity of withholding influences (by regulators, environmental NGOs), usage influences (by customers) and employee influences (through involvement) were identified by managers. Preuss et al. (2009) found especially employee representatives and trade unions as important demanders. Spence (2009) identified investors and employees as being overwhelmingly the most important audiences targeted by social and environmental reporting managers. Huang and Kung (2010) identified three groups 
of stakeholders that greatly influence managerial choices regarding environmental disclosure strategies: external stakeholders (government, debtors, consumers), internal stakeholders (shareholders, employees) and intermediate stakeholders (environmental NGOs and accounting firms). Furthermore, employee demands are not related only to general CSR, but to environmental issues in particular. For instance Marshall et al. (2005) found employee welfare to be an important driver for proactive environmental behavior in the US wine industry. This approach assumes employees as a coherent and collective group of individuals who unanimously demand responsible action from management.

Another main stream of research connects employees to internal organizational changes to promote responsibility. This discussion has focused especially on the question of developing a strongly integrative responsibility-oriented organizational culture (Dodge, 1997; Del Brio et al, 2008). The process of developing such a culture has mainly been viewed through the concepts of sustainability and environmentalism as a collective learning process (Halme, 1997; Halme, 2002; Siebenhuner and Arnold, 2007; Haugh and Talwar, 2010; Benn and Martin, 2010; Del Brio et al., 2008) with the aim of creating a holistic, shared understanding of responsibility in an organization. Furthermore, the influence of managerial behavior on responsibility challenges has been identified as being crucial in engaging employees to tackle the problems (Wolf, 2012; Ramus, 2002; Baumgartner, 2009). The findings of Aragon-Correa et al. (2004) and Robertson and Barling (2012) support the central role of executives in the so-called greening of an organization. Ramus (2002) further emphasizes the importance of managerial tools (education, participative communication and rewarding for sustainability) for such change: supervisory behavior can positively affect employees' environmental actions and initiatives. Collier and Esteban (2007) focus on effective delivery of CSR practices-and state that only the employees "whose value and vision are fully aligned with those of the organization will handle these situations effectively" (p. 30). They conclude that it is necessary for ethics and responsibility to become embedded in the culture of the organization. They further point out that corporations have developed a range of CSR practices, like such as codes of conduct, which seek to regulate the behavior of employees. Marshall et al. (2005) follow the main stream as they stress the need for infusing strong environmental values among employees throughout the company. Zwetsloot (2003) highlight the importance of continuous learning related to management system development in regards to CSR. 
The above mentioned approaches to the role of employees in CSR both assume employees as a coherent group or stakeholder that shares, or eventually comes to share, approaches to CSR. However, some studies have highlighted the different perceptions of CSR among employees. Both Howard-Grenville (2006) and Linnenluecke et al. (2009) identify differences in employees' understandings, but they explain the different interpretations by the existence of different subcultures in organizational culture. Harris and Crane (2002) identify confusion concerning the definitions and differences between various concepts of organizational environmentalism among managers and cultural greening not as a simple, one-dimensional concept. Baumgartner (2009) identified discussions, uncertainty and tensions about sustainable development, especially about further development regarding corporate sustainable development activities. Other research has identified individual differences in employees' orientation to CSR based, for on the age of employee (Lipsett 2012). Furthermore, Ramus and Killmer (2007) point out problems in the organizational integration of CSR: corporate greening behaviors are not often formally required for an employee's job and may suffer from a lack of clear goals or certainty about organizational rewards. On the other hand, Zhu et al. (2012) and Alniacik et al. (2011) showed the positive outcomes of CSR from the employee perspective. Alniacik et al. found that positive CSR information enhances a potential employee's intentions to seek employment. Zhu et al. found worker satisfaction and commitment persists as long as management is perceived to be making clear CSR efforts for employees, such as enhancing the future security of their jobs.

Similar to the first main stream, which focused on employees as a stakeholder, this second stream assumes employees as a unified group sharing views of corporate social responsibility. However, the main difference is in the perspective that the latter one stresses the need for change if management perceives that responsibility values are not shared in the organization. If we perceive CSR only as top-down managed change process, we encounter two major problems from the employee perspective: 1) the CSR approach of the organization only relies on the managerial interpretation of the organization, not on that of the employees who are supposed to implement it; and 2) The employees will easily question the CSR approaches that are distant from their own work. 
Emotions in work organizations have been defined from the social perspective: According to Rafaeli and Worline (2001), emotions are essentially social, just as people are. Fineman and Sturdy (1999) stress that emotions need to be understood in terms of the social structures of which they are a part. Furthermore, Weiss and Cropanzano (1996, p. 17) state that

Emotions are intuitively well understood yet a definitive definition of emotion has been difficult to come by....an emotional reaction is not just one reaction but a constellation of related reactions.

Emotions have been viewed from different perspectives (see Fineman and Sturdy 1999, p. 634), and the social perspective makes a distinction between the subjective experience of emotions (feelings) and their personal/dramatic displays (emotions) (Fineman, 1996b; Fineman and Sturdy, 1999). Fineman (1996b, p. 289) explains:

For those who spend much of their time in organizations, emotion talk is often taken for granted: the gripes, the anger, the anxiety, the frustrations; the glee, the joy, the tedium, the embarrassments, the despair. These are part of social creation and personal expression of work and organizational life.

As Rafaeli and Worline (2001) suggest, emotions emerge within social collectives, so work organizations are filled with emotions. Fineman (1996b) goes further, stating that work activities are shaped by emotions.

Prior research on environmental responsibility has identified the emotional subtexts of corporate greening (Fineman, 1996a), emotions related to environmental control (Fineman and Sturdy, 1999) and the dangers of using dramatic and emotional language in representing environmental issues in business (Andersson and Bateman, 2000). Fineman (1996a) identified four emotionally significant subtexts for corporate greening: enacting green commitment, contesting green boundaries, defending autonomy and avoiding embarrassment. These emotional subtexts were related to the way green pressures were received and culturally incorporated or rejected by senior managers in six UK supermarkets. It is especially noteworthy that managers do not relate negative emotions only to rejecting green pressures and defending autonomy. Many managers were keenly aware that they could be embarrassed by criticism of their environmental record. Fineman and Sturdy (1999) continued research on emotions in relation to environmental issues, as they identified emotions of control among environmental regulatory inspectors and industrial managers in the UK. Andersson and Bateman (2000) noted in their study that the use of dramatic and 
emotional language in presenting environmental issues to gain top-management support was not a significant predictor in the outcome of any championing episodes. Rather the use of drama and emotion may have had a negative impact on the success of championing episodes. Besides the environmental dimension, one can find surprisingly little evidence on the emotions employees connect with CSR

Negative and positive affectivity are the main components of emotions (Weiss and Cropanzano, 1996; Russell and Griffiths, 2008). Emotions can be represented in terms of these two distinct dimensions. (Weiss and Cropanzano, 1996). As Fineman (1996a) shows, both positive and negative emotions play a role in the adaptation of proenvironmental behaviors within organizations. Managers spoke of positive emotions in relation to commitment to environmental issues (such as belonging, respect, awe and loyalty) but also negative emotions played a role, especially fear and embarrassment. Thus there is evidence that both positive and negative emotions can result in pro-environmental behavior.

In prior research, Rupp et al. (2006) stress the importance of employees' emotions to CSR. According to them, employees' perceptions of CSR trigger emotional, attitudinal, and behavioral responses. They form a theoretical proposition on employees' perceptions CSR which states (p. 540):

Employee perceptions of CSR will exert positive effects on individually relevant outcomes such as organizational attractiveness, job satisfaction, organizational commitment, citizenship behavior, and job performance. Employee perceptions of CSR will exert negative effects on individually-relevant outcomes such as anger.

Similar to the proposition of Rupp et al. (2006), Carrus et al. (2008) show that negative anticipated emotions and past behavior are significant predictors of desire to engage in pro-environmental action.

\section{Rhetorical Approach}

This study describes how the types of corporate social responsibility are rhetorically constructed in the interviews with employees, following the assumption that language has the power to contribute to our understanding of the formation of views of certain corporations' CSR (Berger and Luckmann, 1966). This study joins the school of new 
rhetoric born under the influence of the linguistic turn in the 1960s (Billig, 1987; Perelman, 1982; Potter, 1996) and makes no distinction between rhetoric and reality. Here, rhetoric is a part of socially constructed reality. New rhetoric is based on the assumption that it is possible and necessary to classify how credibility emerges for certain claims and on what basis commitment to different conclusions occurs. Unlike studies of realism, constructionist studies do not aim to reveal social reality, but focus on how people construct versions of social reality in social interaction (Burr, 1995). Billig (1987) points out that rhetoric should be seen as a pervasive feature of the way people interact and arrive at understanding. Rhetorical argumentation is an essential quality of all language use and a persuasive feature in social interaction, when people aim to accomplish a common understanding.

The rhetorical approach does not offer an unambiguous, clear research method. It can be understood as a loose theoretical framework that allows opportunities to use and develop different methods for analyzing texts. My loose framework for analysis was guided by the following rhetorical principles:

- Openness: Billig (1987) describes openness as a possibility to present different arguments that, while they may be conflicting, all of them are arguable. Finding just a single correct solution, as required by logic, is impossible. By applying the rhetorical approach, I am interested in the possibility of finding alternative views that Billig (1987) describes as especially characteristic of political, ethical and juridical questions. My interest is in finding competing realities in the texts I have analyzed.

- Emotionality: Gilbert (1995) stresses that scholars have recognized that some arguments are emotional, and some very emotional. They are very contextrelated and occur because there are times when the expression of such feeling is important for us. Furthermore, early on Aristotle (see Summa, 1996; Palonen and Summa, 1996) represented three levels of the means for persuasion: ethos, pathos and logos. Ethos is related to how the speaker presents himself to the audience. Pathos deals with the means that are used for preparing the audience to listen to the speaker, and also thus deals with the interaction in the argumentation and discussion process. Pathos refers to means that are used to decrease any obstacles to communication. That type of persuasion deals with the emotional aspects in argumentation. Logos deals with the logical 
structures of different types of arguments for a certain claim and thus with the abstract content of the claim. (Summa, 1996; Palonen and Summa, 1996).

- Associations and dissociations: Perelman's (1982) theory of argumentation is one of the foundations of the school of new rhetoric. In it the basic idea is to create a dissociation and association (liaisons) between two or more issues. Using liaisons means associative argumentation, creating connections between different phenomena. If arguments are given as dissociation, they aim at separating elements which language or a recognized tradition has previously tied together and thus it structures information in a new way. In dissociation, different sides are separated in the phenomena and they are proportioned to each other or some other phenomena (Perelman, 1982).

\section{Material and Methods}

\section{Research context and material}

Prior research on financial firms' CSR has focused on critical approaches to CSR reporting (Coupland, 2006; Douglas et al., 2004). The financial firm in this study has a clear goal to be a CSR pioneer in the Finnish financial industry. It clearly states this goal on its website. It publishes a responsibility report, participates in multiple CSR projects and some of its employees, including the CEO, are active members in Finnish CSR networks. Furthermore, because the firm is a cooperative owned by its customers, it must meet special requirements of transparency and responsibility. Both the goal to be a CSR pioneer in a less studied business branch and the ownership of the firm offer an especially interesting research setting for this study. The organization employs about 3,000 people. The operations cover banking, financing and insurance services. Recently the corporation has faced a challenge: they downsized 150 employees. From this organization 27 people were interviewed (39-95 min/each) and people from all levels of the organizational hierarchy participated.

A qualitative and interpretative approach (Kovalainen and Eriksson, 2008) was applied in this study because the aim was to understand the richness and complexity of 
interactions and processes in social contexts. All the interviews focused on the meaning of CSR in the interviewees' daily work. All the interviews covered the same four themes: job description of the interviewee, views on CSR in the corporation, internal CSR communication, external CSR communication. All the topics were openly discussed from the viewpoint of the employees' daily job. The questions had an openended structure, for example: Could tell me about your normal work day? How do you relate to CSR in your corporation? How are you informed about CSR?

\section{Analysis}

I analyzed the interviews as argumentative texts in which versions of the employing organization's corporate social responsibility are being constructed, looking especially at the types of emotional arguments used. I read through the interviews several times and noticed that emotions repeatedly emerged when talking about the employing organization's CSR. I then used Atlas.ti for coding all the parts of the interviews in which emotional arguments were explicitly used by the interviewees and reduced the data. I then excluded those parts that did not deal with my research interest. I followed the principles of rhetorical analysis (explained above) to analyze each extract with explicit emotions and listed the emotion, its positive or negative meaning and what the CSR is associated/dissociated with. For representation of the positive and negative meaning, certain contrasts were identified. The interviewees used, for example, certain positively laden emotions in the negative sense (e.g., "disappointment because the firm lacks courage") and vice versa. An example of the coding and analysis process is represented in Table 1.

\section{INSERT TABLE1 ABOUT HERE}

At this point in the analysis I noticed that emotional arguments were used to construct different meanings for the employing organization's CSR. I then continued by analyzing the similarities and differences and arrived at two negative and four positive ways of using emotional arguments to produce meanings of the employing organization's CSR. In all of them the interviewees produced a view of where their 
employing organization's CSR is derived from. The data was originally produced in Finnish, and the analysis process was conducted in the original language. The extracts used in this article were then translated by a professional and checked by the researchers in order to preserve their original meanings.

\section{Results}

During my analysis process I identified six different categories of emotional arguments to construct a view of the employing organization's CSR. Two of them are negatively laden and four of them are positively laden. The negative categories are cynicism and discomfort in one's own work and Irritation and lack of shared courage. The positive categories are: Close to my heart and pride, Shared good will, Distinction from greed and Avoidance of shame. In each of these categories, a view of the employing organization's CSR is constructed that takes a stance on where their employing organization's CSR is derived from. Altogether I analyzed 285 instances of emotions being related to a certain view of the employing organization's CSR. In 91 (32\%) of them, a negative meaning emerged, and in $194(68 \%)$ of them the positive meaning emerged. In the following section I explain the content of each category and the view produced.

Negative Categories

\section{Cynicism and discomfort in one's own work}

The first negative category of emotional arguments is associated with cynicism and discomfort within the boundaries of the employees' daily work. The employing organization's CSR is defined here through individual choices and the work of employees. This category was identified $32(11 \%)$ times in the data. It associates the descriptions of CSR with negative experiences and emotions within their own work. Negative experiences are related, for example, to the difficulty of and boundaries on making responsible decisions in their own work, irresponsible organizational action faced in their own work and to the lack of opportunities to implement responsibility in their own work. Thus the view of CSR constructed here is individualistic. It is especially produced and defined through the boundaries of their own work, through what defines how well or how poorly they can personally implement responsibility in their work. At 
the same time, this argumentation questions organizational support for responsible choices and the work of individuals and considers whether it is even organizationally prevented. The explicit emotions expressed included cynicism, frustration, stress, displeasure and anxiety.

The following extract provides an example of this type of argumentation. Here the interviewee was a person who was partially responsible for CSR issues in the organization (in addition to other duties) and he describes how his attitude toward CSR issues has developed:

At some point a lot of other work came up and I just wasn't able to focus on communicating about CSR as much l'd perhaps have wanted to. And it also felt that at the beginning I believed in the whole issue a bit more. But I have to say that at some point a certain kind of cynicism set in...there just wasn't the possibility for this sort of work and it just started to feel like it was maybe falling on deaf ears. And so my faith just sort of faded.

Table 2 describes the expressed emotions, rhetorical association and the view of where CSR is derived from as constructed in this category.

\section{Irritation and lack of shared courage}

The second negative category of emotional arguments questions the organizational "will and spirit" for responsibility and at the same constructs a view of the employing organization's CSR that would mean shared and collective action. This category was identified $59(21 \%)$ times in the data. The main difference here with "cynicism and discomfort within one's own work" is that this first category relied on an individualistic view of CSR whereas this second category stresses a collective approach. In this argumentation explicit emotions are related to shortcomings of current corporate approaches to responsibility, such as lacking a shared "spirit", a lack of internal changes, distance between CSR and usual employee, lack of CSR in daily practices and poor practical implementation. In extreme cases, current approaches to CSR were described as publicity stunts and related to green washing. This argumentation questions whether the corporation is really responsible or whether it only talks like it 
would be. The explicit emotions expressed included annoyance, disappointment over the lack of good heart and courage, cynicism, anxiety and uncertainty.

In the following example an interviewee expresses his annoyance over current CSR practices in the organization and questions whether it is only done as a duty like in all other big firms:

Yeah, sure, it's great that these things get thought about, but it's kind of a pity that the way they get implemented in practice is pretty poor, that there's a bit of a feeling that this is kind of a given, that these things are done only because these days a big company is supposed to have some environmental responsibility and corporate responsibility thing, that it's not now...I guess it's just that the whole thing should be a little more visible in practice too.

Table 3 describes the expressed emotions, rhetorical association and the view of where CSR is derived from as constructed in this category.

\section{Positive Categories}

\section{Close to one's heart and pride}

The first positive category of using emotional arguments associates CSR with its importance in an individuals' own work and with personal commitment. This category was identified $39(14 \%)$ times in the data. The category relies on a similar perspective of the employing organization's CSR as the category Cynicism and discomfort within one's own work, namely, that CSR is defined in the individual choices and work of employees. Here, however, the argumentation leans on positive emotions related to one's own work. The argumentation constructs a view of a responsible employee for whom personal commitment to CSR is important. It happens by stressing the importance of their own work for the employer's CSR, by expressing the personal commitment to CSR and by expressing the importance of personal values to responsibility. Typically for this argumentation the interviewees explained that responsibility has great importance for them and CSR is "close to my heart". In this case the approach to CSR was individualistic: produced through personal commitment 
and personal promotion of CSR. The explicit emotions expressed included pride, enthusiasm, gratification and fulfillment.

The following extract is an example of this argumentation. The interviewee describes her own commitment to CSR and continues by showing how the values are promoted in the organization.

I've usually taken part in all the extra projects with enthusiasm and this responsibility issue is one that is actually pretty close to my heart. If you think about it, when getting familiar with the field for example, so we try to say how they should work in practice so that everything in all ways goes right and responsibly.

Table 4 describes the expressed emotions, rhetorical association and the view of where CSR is derived from as constructed in this category.

\section{INSERT TABLE 4 ABOUT HERE}

\section{Shared good will}

The second positive category of emotional arguments associates positive emotions with shared values and a "spirit" of responsibility in the organization. This category was identified $72(25 \%)$ times in the data and thus it was the most frequently used in the data. This is expressed in two meanings in the data: by descriptions of shared values between individual employees and organizational values, and by descriptions of a shared spirit for CSR among organizational members. Shared values between an employee and the organization are described as organizational values "with which one can identify" and in statements such as the following: "It would be hard to work somewhere that didn't operate according to my values" and "I like it here, because this company reflects my values". Shared spirit among organizational members was found in statements that expressed "pride in the shared values, pride that nobody resists CSR, being happy that they could not complain about their colleagues, and that employees "can sell with good conscience". The view of CSR constructed here was collective, produced and defined in collective shared values and mindsets. At the same time, this argumentation led to a view of an integrated organizational culture concerning CSR. The explicit emotions expressed included liking, comfort, identification, pride, positivity, good will and agreement. 
The following extract is an example of this argumentation. The interviewee responded to the question of whether it is significant for him to be employed in an organization that practices CSR.

Interviewee: I can't, I can't, well, it would be hard for me to work somewhere that operated against my own values.

Interviewer: I see. Which of your own values especially connect with (financial firm's) business?

Interviewee: Well, for example, there's how, well, there's how, when you meet someone else, so how you treat that other person in that situation, whether it's a customer, a customer, or like someone from the staff, someone, whoever, a partner.

Table 5 describes the expressed emotions, rhetorical association and the view of where CSR is derived from as constructed in this category.

\section{Distinction from greed}

The third positive category of emotional arguments is constructed with different argumentation tactics: instead of using emotional arguments for association, it creates dissociation between the employing organization and other businesses. In addition, both positively and negatively laden emotional arguments are used for constructing this distinction. This category was identified $36(13 \%)$ times in the data. It is especially based on the organizational form of the firm as a co-operative owned by its customers. This ownership model, according to the employees, leads to totally different premises for business action as well as for corporate social responsibility compared with publicly traded companies. Because the firm is a co-operative it leads to business that is, according to the interviewees, "more humane instead of cold and serious" and to building all the operations on the principle that the "other party is respected". In this argumentation, the interviewees construct the view that who own a company and how has a great influence on CSR. The explicit emotions expressed are both positively (to describe the employing organization) and negatively laden (to distinguish other businesses). The explicit emotions expressed include disgust over a company's greed, gentleness, respect and coldness. 
The following extract provides an example of this type of argumentation. The interviewee holds a managerial position in the organization and has previously worked in many publicly traded companies. The interviewee uses the image of a "greedy hand on the leadership's neck" to dissociate the current employer from prior ones:

Or then in (a corporation) or (a corporation) in 2006 when this kind of program really got underway, I just started thinking that it was, like, somehow, these things are just coming from a totally different set of parameters. Like it's somehow that the shareholder value and analysts' demands kind of decided things, and at the management level some representative listened for what the analysts were demanding. In other words, it was like the greedy hand of some third party had the leadership, like, by the neck. So even though this place maybe felt a little boring at the beginning, now it's just like this unbelievable feeling to make it to a place like this.

Table 6 describes the expressed emotions, rhetorical association and the view of how and where CSR is defined as constructed in this category.

\section{Avoidance of shame}

The fourth positive category of emotional arguments associates the view of CSR with external feedback. This category was identified 47 times (16\%) in the data. Positively laden emotional arguments are used to construct a good and responsible external reputation for an employer. This is related especially to the feedback from the customers but also to the feedback employees get from neighbors, friends and other people in informal situations during their leisure time. Here the employees expressed that they need not be "embarrassed" or "grovel" and explain that "there haven't been any negative situations. Here, CSR is defined in the interaction with the external actors through the external reputation of the corporation. In addition to the corporation, a couple of interviewees related responsibility to the whole financial sector, in which, according to them, one cannot act irresponsibly. The explicit emotions expressed include pride, comfort and confidence with no need to feel ashamed or grovel, happiness and trust. 
The following extract is an example of this argumentation. Here the interviewee explains how he feels about his organization during his leisure time and dissociates the reputation of the employer from Icelandic banks, which got a bad reputation during Iceland's financial crisis in 2008 and 2009.

I talk about it with pride. I don't have any feelings at any point that there should be some reason to be ashamed. It's just like, I work for (name of the employer)....an employer, yeah, that's respected and maybe there hasn't been anything negative about it, you know, there's no need to admit at all that at some point there's been some failed Icelandic bank involved along the way. In that regard that, you know, I can honestly say that there just hasn't been that kind of thing when, like, a customer says that things are bad with us and all, you know, I can always kind of ask in what way and justify it. You just can't find that stuff. That's why l'm proud.

Table 6 describes the expressed emotions, rhetorical association and the view of where their employing organization's CSR is derived from as constructed in this category.

\section{Emotions categories and their amounts in the interviews}

Table 8 presents a list of interviewees. The list includes their position in the organization, categorized roughly into managers (e.g. CEO, head of finance, HR and communications, expert (e.g. experts from internal services, risk management and communications) and other employees (e.g. employees working for customers services and internal services), and their gender. The table then describes how many of the emotions mentioned by each interviewee fell into different categories of emotional arguments. To guarantee the anonymity of the interviewees, departments or more detailed job descriptions are not mentioned in the table.

As the table shows, in both the positive (72/194) and the negative (59/91) emotion categories, the most frequent definitions were those that viewed CSR as a collective action internally in the organization. Thus the internal spirit for CSR, policies and other shared, organizational actions invoke positive emotions (employees experienced CSR as something shared) and negative emotions (employees experiencing CSR as something that is not yet shared in the organization). 
However, the results do not show the possible differences between positive and negative emotions expressed by different employee groups (managers, experts and other employees). In each of these groups both positive and negative emotions are frequently expressed in different meanings.

-INSERT TABLE 8 ABOUT HERE-

\section{Discussion and conclusion}

This study showed that employees use emotional arguments to construct different views of where their employing organization's CSR derives from: individual action, collective action, ownership or external reputation. More specifically, they related positive emotion to those issues which, they felt, had promoted CSR. On the other hand, they related negative emotions to issues in which, according to them, the corporation has not achieved CSR. When it comes to individual action and sharing responsibility within the organization, both positive and negative views were represented, also to question whether the employing organization is really responsible. Descriptions of collective action dominated the negative and positive categories. However, the co-operative form of the corporation as well its external reputation were represented in a positive sense only, building the view that the corporation has been successful with its CSR.

These results contribute to our understanding of the importance of employees' emotions for CSR and shows the importance they place on their employer's CSR in relation to their commitment. Still, the emotions they wish to avoid make a more important contribution. Especially the prior stakeholder-oriented literature (McWilliams and Siegel, 2001; Sharma and Henriques, 2005) has shown that managers experience CSR pressures from stakeholders, including employees. However, the results of this study show that not only managers experience these pressures but also employees, although in a different form. As described in the category of shame avoidance, the employees especially wish to get positive feedback in face-to-face situations, not only 
from their customers but also from other peer groups. They do not wish to be embarrassed by their employer. Although this demand is not explicitly stated by their social networks, it is implicit as an assumption that nobody wishes to work with the socalled bad guys. Thus the results show that the employing organization's CSR is not simply important for employees as targets of responsibility (e.g. responsible human resource practices) but also participants in CSR. These findings support the findings of Fineman's (1996a), Rupp et al. (2006) and Carrus et al. (2008) on the importance of negative emotions (or fear of them) for responsible behavior. Fineman in particular noticed that managers do not relate negative emotions only to rejecting green pressures and defending autonomy but also many managers were keenly aware that they could be embarrassed by criticism of their environmental record. This study showed similar pattern for employees concerning CSR. They are aware that they could be embarrassed if the employer had an irresponsible reputation.

Second, the results show that the role of employees in CSR is more divergent than the mainstream literature assumes. As much of the literature focuses on employees as a coherent group of stakeholders (Jamali, 2008; Longo et al., 2005; Royle, 2005; Preuss et al., 2009; McWilliams and Siegel, 2001) and on top-down managed changes for sharing responsibility (Halme, 2002; Siebenhuner and Arnold, 2007; Haugh and Talwar, 2010; Benn and Martin, 2010; Del Brio et al., 2008), the study shows that the employees assign different meanings to CSR through their argumentation, especially in the question of where it is derived from. In taking these shifting meanings into account in CSR practices and management, companies face a challenge: What is implemented in the name of CSR may be interpreted as irresponsible among employees, or as mere green washing. The emotions related to individual action possibilities and organizational spirit (collective) were split into positive and negative categories, as shown in Table 8. This division of emotions might be viewed as a weakness - especially in an organization that is clearly aiming to be a CSR pioneer in its own industry. I argue that such a division is really a strength. It offers a possibility to initiate internal discussions on CSR and its significance for individual jobs and as a shared experience in the organization. The discussion can be started by asking questions such as "What are you proud of?" and "What are you embarrassed by?" This type of discussion should be promoted in CSR communication and HR management in an organization to support the further development of CSR. Some 
studies have suggested that while promoting responsibility in an organization emotions should be put aside and responsibility should be framed in the language of business cases (Andersson and Bateman 2000). Based on the results of this study, I propose that CSR is an emotional issue for businesses and thus should be dealt with in emotional terms.

Another possible change businesses could make in their HR-related CSR practices is to decrease the use of the term employee engagement. In many cases, CSR is seen as something that you need to engage employees in. However, the results of this study show that the employees are already engaged in CSR issues naturally, for they place great (emotional) importance on it. To engage the employees who are already engaged, there should be more possibilities for defining and discussing, even in negative emotional terms. Such a discussion could be a source of more change.

This study does include limitations that need to addressed in the future research. These include its limited data; the social, business sector and national context; and the theoretical and methodological approaches applied. However, the study also highlights a crucial issue that has been neglected in prior research, namely, the importance of emotions to how CSR is perceived and the actions taken under its name. Emotions exert more influence over views of CSR than has previously been noted, which also explains how personal these views are. To deepen our understanding of how emotions relate to CSR, further research is needed using different theoretical and methodological approaches, more data sets and in different contexts. In particular, negative emotions related to CSR offer possibilities for further research. Prior to this study, one might have hypothesized that there is a major difference between managers and other employees in the way they relate positive and negative emotions to CSR. However, no such difference was noticed in the results of this study (see Table 8). Both groups frequently mention both types of emotions. Instead, future studies cold hypothesize that, independent of individuals' position in a firm, experiences and emotions are similar. A further fruitful topic for research that emerged in these results related to the cooperative as an organizational form. We need more information on how organizational form relates to employees' experiences of their employing organizations' CSR. 


\section{References}

Aguilera RV, Rupp DE, Williams CA and Ganapathi J. 2007. Putting the S Back in Corporate Social Responsibility: A Multilevel Theory of Social Change in Organizations. Academy of Management review 32 (3): 836-863.

Alniacik U, Alniacik E and Genc N. 2011. How corporate social responsibility information influences stakeholder's intentions. Corporate social responsibility and environmental management 18 : 234-245. DOI: 10.1002/csr.245.

Andersson $L$ and Bateman T. 2000. Individual Environmental initiative: Championing natural environmental issues in U.S. business organizations. Academy of Management Journal 43 (4): 548-570.

Aragon-Correa J, Matias-Reche F and Senise-Barrio M. 2004. Managerial discretion and corporate commitment to the natural environment. Journal of Business research 57: 964-975.

Bansal P and Roth K. 2000. Why companies go green: A model of ecological responsiveness. Academy of management journal 43 (4): 717-736.

Baumgartner RJ. 2009. Organizational culture and Leadership: preconditions for the development of a sustainable corporation. Sustainable development 17: 102-113.

Berger PL and Luckmann T. 1966. Social construction of reality. A treatise in the sociology of knowledge. Garden City: New York

Billig M. 1987. Arguing and thinking. A rhetorical approach to social psychology. University Press: Cambridge

Burr V. 1995. An introduction to social constructionism. Routledge: London

Carroll A. 1999. Corporate social responsibility: Evolution of a definitional construct. Business \& Society 38 (3): 268-295.

Carroll AB.1993. Business \& Society. Ethics and Stakeholder Management. South Western Publishing Co: Cincinnati

Carrus G, Passafaro P and Bonnes M. 2008. Emotions, habits and rational choices in ecological behaviours: The case of recycling and use of public transportation. Journal of environmental psychology 28: 51-62. DOI: 10.1016/j.jenvp.2007.09.003.

Celma D, Martinez-Garcia E, Coenders G. 2012. Corporate social responsibility in human resource management: an analysis of common practices and their determinants in Spain. Corporate social responsibility and environmental management. DOI: 10.1002/csr.131. 
Collier J. and Esteban R. 2007. Corporate social responsibility and employee commitment. Business ethics: a European review 16 (1): 19-33. DOI: 10.1111/j.14678608.2006.00466.x

Coupland C. 2006. Corporate social and environmental responsibility in web-based reports: Currency in the banking sector? Critical Perspectives on Accounting 17: 86588. DOI: 10.1016/j.cpa.2005.01.001

Dahlsrud A. 2008. How corporate social responsibility is defined: an analysis of 37 definitions. Corporate social responsibility and environmental management 15: 1-13. DOI: $10.1002 /$ csr.132

Del Brio JA, Junquera B. and Ordiz M. 2008. Human resources in advanced environmental approaches - a case analysis. International Journal of Production Research 46 (21): 6029-6053. DOI: 10.1080/00207540701352094

Dobers P. Corporate social responsibility: management and methods. Corporate social responsibility and environmental management 16: 185-191.

Dobers P. and Halme M. 2009. Editorial Corporate social responsibility and developing countries. Corporate social responsibility and environmental management 16: 237-249. DOI: 10.1002/csr.212.

Dodge J. 1997. Reassessing culture and strategy: Environmental improvement, structure, leadership and control. In Welford R (Ed.) Corporate environmental management and. 2. Culture and organizations. Earthscan: London.

Douglas A, Doris J and Johnson B. 2004. Corporate social reporting in Irish financial institutions. The TQM Magazine 16 (6): 387-395. DOI: 10.1108/09544780410563301.

Elkington J. 1997. Cannibals with forks: the triple bottom line on 21st century business. Capstone: Oxford.

Eriksson P. and Kovalainen A. 2008. Qualitative methods in business research. Sage: London

Fineman S. 1996a. Emotional subtexts in Corporate Greening. Organization studies 17 (3): 479-500.

Fineman S. 1996. Emotions and organizing. In Clegg, Hardy, C. and Nord, W.R. (Eds.) Handbook of organization studies. Sage: London.

Fineman S. 2001. Fashioning the Environment. Organization 8 (1): 17-31.

Fineman S. and Sturdy A. 1999. The Emotions of Control: A Qualitative Exploration of Environmental Regulation. Human relations 52: 631-663.

Friedman M. 1970. The social responsibility of business is to increase its profits. Wilson L. (ed. 2000). Business Ethics and Contemporary Issues. Kendall/Hunt Publishing company: Dubuque, lowa 
Gilbert MA. 1995. What is an emotional argument? Or why do argument theorists quarrel with their mates? Analysis and Evaluation: proceedings of the third ISSA Conference on Argumentation Vol 2, F.H. van Eemeren, R. Grootendorst, J.A. Blair and C.A. Willard, eds. Amsterdam 1994. Sic Sat: Amsterdam.

Halme M. 1997. Developing an environmental culture through organizational change and learning. In Welford, R. (Ed.) Corporate environmental management and. 2. Culture and organizations. Earthscan: London.

Halme M. 2002. Corporate environmental paradigms in shift: learning during the course of action at UPM-kymmene. Journal of Management studies 39 (8): 1187-1109.

Harris L and Crane A. 2002. The greening of organizational culture. Management views on the depth, degree and diffusion of change. Journal of organizational change management 15 (3): 214-234.

Haski-Leventhal D. 2012. Employee engagement in CSR: the case of payroll giving in Australia. Corporate social responsibility and environmental management DOI: 10.1002/csr.1287.

Haugh N and Talwar A. 2010. How do corporations embed sustainability across the organization? Academy of management learning \& education 9 (3): 384-396.

Henriques I and Sadorsky P. 1999. The Relationship between Environmental Commitment and Managerial Perceptions of Stakeholder importance. Academy of Management Journal 42: 87-99

Howard-Grenvill J. 2006. Inside the "black box". How organizational culture and subcultures inform interpretations and actions on environmental issues. Organization \& Environment 19 (1): 46-73.

Huang C and Kung F. 2010. Drivers of environmental disclosure and stakeholder expectation: evidence from Taiwan. Journal of Business Ethics 96: 435-451. DOI: 10.1007/s10551-010-0476-3

Jamali D. 2008. A Stakeholder Approach to Corporate Social Responsibility: A Fresh Perspective into Theory and Practice. Journal of Business Ethics 82: 213-231. DOI: $10.1007 / \mathrm{s} 10551-007-9572-4$

Linnenluecke M, Russell S and Griffiths A. 2009. Subcultures and sustainability practices: the impact on understanding corporate sustainability. Business strategy and the environment 18: 432-452. DOI: 10.1002/bse.609

Longo M, Mura M and Bonoli A. 2005. Corporate Social Responsibility and Corporate Performance: The Case of Italian SMEs'. Corporate Governance 5 (4): 28-42. DOI: 10.1108/14720700510616578. 
Marshall R, Cordano M and Silverman M. 2005. Exploring individual and institutional drivers of proactice environmentalism in the US wine industry. Business Strategy and the Environment 14 (2): 92-109. DOI: 10.1002/bse.433.

McWilliams A and Siegel D. 2001. Corporate social responsibility: a theory of the firm perspective. Academy of Management Review 26 (1): 117-127.

Michailides T and Lipsett M. 2012. Surveying employee attitudes on corporate social responsibility at the frontline level of an energy transportation company. Corporate social responsibility and environmental management. DOI: 10.1002/csr.1291.

Palonen K and Summa H. 1996. Johdanto: retorinen käänne? In Palonen K and Summa H. (eds.) 1996. Pelkkää retoriikkaa. Tutkimuksen ja politiikan retoriikat. Vastapaino: Tampere

Perelman C. 1982. The Realm of Rhetoric. Notre Dame: London.

Potter J. 1996. Representing reality: discourse, rhetoric and social construction. Sage publications Itd: London.

Preuss L, Haunschild A and Matten D. 2009. The Rise of CSR: implications for HRM and employee representation. The international Journal of Human Resource Management 20 (4): 953-973. DOI: 10.1080/09585190902770893

Rafaeli A and Worline M. 2001. Individual emotion in work organizations. Social Science Information 40 (1): 95-123.

Ramus C and Killmer A. 2007. Corporate greening through prosocial extrarole behaviours - A conceptual framework for employee motivation. Business strategy and the environment 16: 554-570. DOI: $10.1002 / \mathrm{bse} .504$.

Ramus C. 2002. Encouraging innovative environmental actions: what companies and managers must do. Journal of world business 37: 151-164

Ramus C and Steger U. 2000. The roles of supervisory support behaviors and environmental policy in employee "ecoinitiatives" at leading -edge European companies. Academy of Management Journal 43 (4): 605-626.

Robertson J and Barling J. 2012. Greening organizations through leaders' influence on employees pro-environmental behaviors. Journal of organizational behavior DOI: 10.1002/job.1820.

Royle T. 2005. Realism or idealism? Corporate social responsibility and the employee stakeholder in the global fast-food industry. Business ethics: A European Review 14 (1): 42-55. DOI: 10.1111/j.1467-8608.2005.00385.x.

Rupp DE, Ganapathi J, Aguilera RV and Williams C. 2006. Employee reactions to corporate social responsibility: an organizational justice framework. Journal of Organizational Behaviour 27: 537-543. 
Russell S and Griffiths A. 2008. The role of emotions in driving workplace proenvironmental behaviors. In Zerbe, W., Hartel, C. \& Ashkany, N. (eds.) Research on Emotion in Organizations. Volume 4: Emotions, Ethics and Decision-Making. 4: 83107. DOI: 10.1016/S1746-9791(08)04004-2.

Sharma, S., Henriques, I. 2005. Stakeholder influences on sustainability practices in the Canadian forest products industry. Strategic Management Journal 26: 59-180.

Siebenhuner B and Arnold M. 2007. Organizational learning to manage sustainable development. Business strategy and the environment 16: 339-353. DOI: 10.1002/bse.579.

Spence C. 2009. Social and environmental reporting and the corporate ego. Business Strategy and the Environment. 18: 254-265. DOI: 10.1002/bse.600.

Summa H. 1996. Kolme näkökulmaa uuteen retoriikkaan. Burke, Perelman ja Toulmin ja retoriikan kunnianpalautus. In Pelkkää retoriikkaa. Palonen, K.\& Summa, H. (ed). Vastapaino: Tampere.

Weiss $\mathrm{H}$ and Cropanzano R. 1996. Affective events theory: a theoretical discussion of the structure, causes and consequences of affective experiences at work. Research in organizational behavior 18: 1-74.

Wolf J. 2012. Improving sustainable development of firms: the role of employees. Business Strategy and the Environment 22 (2): 92-108. DOI: 10.1002/bse.1731.

Zhu Q, Hang Y, Liu J and Lai K. 2012. How is employee perception of organizational efforts in corporate social responsibility related to their satisfaction and loyalty towards developing harmonious society in Chinese enterprises? Corporate social responsibility and environmental management . DOI: 10.1002/csr.1302.

Zwetsloot, G. 2003. From Management Systems to Corporate Social Responsibility. Journal of Business Ethics 44: 201-207. DOI: 10.1023/A:1023303917699 


\section{TABLES}

\begin{tabular}{|l|l|}
\hline Extract from interview & $\begin{array}{l}\text { Of course l'm not the right person to evaluate it but I definitely } \\
\text { experience it, because I'm really proud that it [responsiblity] is so } \\
\text { important for us, central to our, like, values and a central, essential } \\
\text { part of our, like, business. }\end{array}$ \\
\hline Emotion mentioned & Pride \\
\hline $\begin{array}{l}\text { Positive/negative } \\
\text { meaning }\end{array}$ & Positive \\
\hline Association/Dissociation & Association with shared values in the organization \\
\hline View of CSR & Derived from collective action \\
\hline
\end{tabular}

Table 1. Example of the analysis process

\begin{tabular}{|l|l|l|}
\hline Explicit emotions & Association/Dissociation & CSR derived from \\
\hline $\begin{array}{l}\text { Cynicism, frustration, stress, } \\
\text { displeasure and anxiety }\end{array}$ & $\begin{array}{l}\text { Associated with descriptions of } \\
\text { negative sides in one's own } \\
\text { work }\end{array}$ & $\begin{array}{l}\text { In individual choices and work } \\
\text { of employees }\end{array}$ \\
\hline
\end{tabular}

Table 2. Cynicism and discomfort in one's own work

\begin{tabular}{|l|l|l|}
\hline Explicit emotions & Association/dissociation & CSR derived from \\
\hline $\begin{array}{l}\text { Annoyance, disappointment } \\
\text { over the lack of good heart } \\
\text { and courage, cynicism, anxiety } \\
\text { and uncertainty }\end{array}$ & $\begin{array}{l}\text { Associated with shortcomings } \\
\text { of the current corporate } \\
\text { approaches to responsibility }\end{array}$ & In collective action \\
\hline
\end{tabular}

Table 3. Irritation and lack of shared courage

\begin{tabular}{|l|l|l|}
\hline Explicit emotions & Association/dissociation & CSR derived from \\
\hline $\begin{array}{l}\text { Pride, enthusiasm, } \\
\text { gratification and fulfillment }\end{array}$ & $\begin{array}{l}\text { Associated with importance of } \\
\text { responsibility to own work as } \\
\text { well as personal commitment to } \\
\text { CSR }\end{array}$ & $\begin{array}{l}\text { In individual choices and work } \\
\text { of employees }\end{array}$ \\
\hline
\end{tabular}

Table 4. Close to one's heart and pride

\begin{tabular}{|l|l|l|}
\hline Explicit emotions & Association/dissociation & CSR derived from \\
\hline $\begin{array}{l}\text { Liking, comfort, identification, } \\
\text { pride, positivity, good will and } \\
\text { agreement }\end{array}$ & $\begin{array}{l}\text { Associates positive meanings } \\
\text { to shared values and "spirit" in } \\
\text { the organization }\end{array}$ & $\begin{array}{l}\text { In collective action and shared } \\
\text { values }\end{array}$ \\
\hline
\end{tabular}

Table 5. Shared good will 


\begin{tabular}{|l|l|l|}
\hline Explicit emotions & Association/dissociation & CSR derived from \\
\hline $\begin{array}{l}\text { Disgust over greed, } \\
\text { gentleness, respect, coldness }\end{array}$ & $\begin{array}{l}\text { Dissociate (both with positively } \\
\text { and negatively laden emotions) } \\
\text { the own employer from } \\
\text { "irresponsible business" }\end{array}$ & $\begin{array}{l}\text { In who owns the company and } \\
\text { how }\end{array}$ \\
\hline
\end{tabular}

Table 6. Distinction from greed

\begin{tabular}{|l|l|l|}
\hline Explicit emotions & Association/dissociation & \\
\hline $\begin{array}{l}\text { Pride, comfort and confidence } \\
\text { with no need to feel ashamed } \\
\text { or grovel, happiness, and trust }\end{array}$ & $\begin{array}{l}\text { Associated with external } \\
\text { feedback, especially reputation }\end{array}$ & $\begin{array}{l}\text { In external relationships, } \\
\text { especially through reputation }\end{array}$ \\
\hline
\end{tabular}

Table 7. Avoidance of shame

\begin{tabular}{|c|c|c|c|c|c|c|c|c|}
\hline Interview & $\begin{array}{l}\text { Interviewee } \\
\text { description }\end{array}$ & Cynicism & Irritation & $\begin{array}{l}\text { Close } \\
\text { to } \\
\text { one's } \\
\text { heart } \\
\text { and } \\
\text { pride } \\
\end{array}$ & $\begin{array}{l}\text { Shared } \\
\text { good } \\
\text { will }\end{array}$ & $\begin{array}{l}\text { Distinction } \\
\text { from } \\
\text { greed }\end{array}$ & $\begin{array}{l}\text { Avoidance } \\
\text { of shame }\end{array}$ & Total \\
\hline 1 & $\begin{array}{l}\text { expert, } \\
\text { female }\end{array}$ & 7 & 4 & 2 & 4 & - & 4 & 21 \\
\hline 2 & $\begin{array}{l}\text { manager, } \\
\text { male }\end{array}$ & - & 1 & 3 & 5 & - & 1 & 10 \\
\hline 3 & $\begin{array}{l}\text { expert, } \\
\text { female }\end{array}$ & 1 & 2 & 3 & 1 & - & 1 & 8 \\
\hline 4 & $\begin{array}{l}\text { expert, } \\
\text { male }\end{array}$ & 3 & 3 & 1 & 2 & - & 1 & 10 \\
\hline 5 & $\begin{array}{l}\text { other } \\
\text { employee, } \\
\text { female }\end{array}$ & 1 & 5 & 2 & - & - & 3 & 11 \\
\hline 6 & $\begin{array}{l}\text { expert, } \\
\text { female }\end{array}$ & 2 & 5 & 2 & 2 & 1 & 2 & 14 \\
\hline 7 & $\begin{array}{l}\text { expert, } \\
\text { female }\end{array}$ & 4 & 3 & 3 & 5 & - & 5 & 20 \\
\hline 8 & expert, male & - & - & 3 & 2 & 1 & 2 & 8 \\
\hline 9 & $\begin{array}{l}\text { other } \\
\text { employee, } \\
\text { female }\end{array}$ & - & 1 & 5 & 8 & 5 & 4 & 23 \\
\hline 10 & expert, male & 4 & 4 & 2 & - & - & - & 10 \\
\hline 11 & expert, male & & 2 & 1 & 1 & - & 1 & 5 \\
\hline 12 & $\begin{array}{l}\text { other } \\
\text { employee, } \\
\text { male }\end{array}$ & 1 & 2 & 1 & 5 & 2 & 2 & 13 \\
\hline 13 & expert, male & - & 2 & 1 & 2 & 2 & 1 & 8 \\
\hline 14 & $\begin{array}{l}\text { manager, } \\
\text { male }\end{array}$ & - & - & 1 & 5 & 5 & 2 & 13 \\
\hline 15 & $\begin{array}{l}\text { other } \\
\text { employee, } \\
\text { male }\end{array}$ & 1 & - & 1 & 3 & - & 3 & 8 \\
\hline 16 & $\begin{array}{l}\text { manager, } \\
\text { female }\end{array}$ & - & 1 & 1 & 9 & 3 & 1 & 15 \\
\hline 17 & $\begin{array}{l}\text { other } \\
\text { employee, } \\
\text { female }\end{array}$ & 3 & 4 & 1 & 1 & 1 & 3 & 13 \\
\hline
\end{tabular}




\begin{tabular}{|l|l|l|l|l|l|l|l|l|}
\hline 18 & $\begin{array}{l}\text { other } \\
\text { employee, } \\
\text { male }\end{array}$ & - & 1 & - & 4 & 2 & 2 & $\mathbf{9}$ \\
\hline 19 & $\begin{array}{l}\text { manager, } \\
\text { male }\end{array}$ & 2 & 2 & - & 3 & 2 & 2 & $\mathbf{1 1}$ \\
\hline 20 & $\begin{array}{l}\text { other } \\
\text { employee, } \\
\text { female }\end{array}$ & 2 & 2 & 4 & 1 & 1 & 2 & $\mathbf{1 2}$ \\
\hline $\begin{array}{l}\text { manager, } \\
\text { female }\end{array}$ & $\begin{array}{l}\text { manager, } \\
\text { male }\end{array}$ & - & 3 & 1 & 2 & 1 & 2 & $\mathbf{9}$ \\
\hline 22 & $\begin{array}{l}\text { manager, } \\
\text { male }\end{array}$ & - & 2 & - & - & 1 & 1 & $\mathbf{5}$ \\
\hline 23 & $\begin{array}{l}\text { other } \\
\text { employee, } \\
\text { male }\end{array}$ & - & 4 & - & 1 & 2 & 1 & $\mathbf{5}$ \\
\hline 24 & $\begin{array}{l}\text { other } \\
\text { employee, } \\
\text { female }\end{array}$ & 1 & 3 & - & 1 & 1 & - & $\mathbf{8}$ \\
\hline 25 & $\begin{array}{l}\text { manager, } \\
\text { male }\end{array}$ & - & - & - & 3 & 2 & 1 & $\mathbf{6}$ \\
\hline 26 & $\begin{array}{l}\text { manager, } \\
\text { female }\end{array}$ & - & - & 1 & 1 & 2 & - & $\mathbf{4}$ \\
\hline 27 & & $\mathbf{3 2}$ & $\mathbf{5 9}$ & $\mathbf{3 9}$ & $\mathbf{7 2}$ & $\mathbf{3 6}$ & $\mathbf{4 7}$ & $\mathbf{2 8 5}$ \\
\hline Total & & & & & & & \\
\hline
\end{tabular}

Table 8. Interviewees and amounts of emotion categories 